\title{
Study Center for \\ Visually Impaired Persons \\ Supportive System for Blind and Partially Sighted \\ Students at the \\ University of Karlsruhe/Germany
}

Joachim Klaus

Studienzentrum für Sehgeschädigte
der Universität Karlsruhe
Engesserstrasse 4
76128 Karlsruhe
Tel.: 0721 - 6082760
Fax: $0721-697377$

\section{Abstract:}

In 1987 a pilot project was started at the University of Karlsruhe dedicated to involve new communication technologies for visually impaired students and the sighted world. This supporting system for blind student led after five years of model development to a Study Center for Visually Impaired Students, which offers equal chances to these handicapped students in steps towards university, in living, learning and examinations inside the university system as well as in steps towards labour market.

\section{Introduction}

In April 1993 the former pilot project "Computer Science for the Blind" at the University of Karlsruhe was institutionalized. It is now called "Study Center for Visually Impaired Persons". From autumn 1987 until spring 1993 the pilot project had been financed by the Federal Mini- 
stry for Education and Science (Bonn) and the Ministry for Science and Art Baden Württemberg. The project's aim was to lead visually impaired persons to study courses and to according profession which were scarcely accessible to them before. This is made possible by

- new technical working aids with special programmes for visually impaired users which have partly been developed at the University of Karlsruhe

- the offer of intensive pedagogical and psychological counselling and care

- specific support concerning study and exam regulations

- further integrative offers like mobility training, university and municipal sports and cultural programmes.

Due to the original offer to support visually impaired persons studying Computer Science and Industrial Engineering, those two study courses are the main subjects being studied but they are complemented by subsidiaries of other faculties.

There is also a close cooperation between the Study Center and the school of Industrial Computer Science at the Fachhochschule of Karlsruhe where visually impaired students are now enrolled, too,

\section{Technical Supporting System}

With the help of modern information technology the blind and partially sighted students gain access to the relevant study literature. Special hard- and software like Braille display, voice output, scanner, large print or print enlargement systems, Braille printer etc. make printed media available to them. The technical support can be divided into the following parts:

1. The technology available within the rooms of the Study Center enables the blind and partially sighted students to quickly and directly exchange e.g. texts, diagrams and drawings among each other or with sighted fellow students. The study literature which is transferred into electronic form is available on diskette and via the local network. 
2. At present there are three decentralized work stations for visually impaired students, one at the university library, one each at the library of the Department of Computer Science and Industrial Engineering which offer the possibility to independently scan printed literature. Further decentralized workstations shall be set up in order to make it possible to work and learn at the same places as their sighted fellow students.

3. For studying an adequate personal technical equipment at home is absolutely necessary. It consists of a powerful personal computer with respective assistive devices as well as a portable unit for taking notes during lectures or seminars. In general this equipment is granted by the relevant Social Security Office for the duration of the studies.

4. Via a speech sever which can be operated by phone some services of the local network and a voicemail function are made available for the students to be used from the outside.

\section{Student assistance}

Textbooks, lecture notes, exercise papers etc. are usually only available in black print, that means blind and partially sighted students have only limited access to that literature. Each term up to 25 student assistants therefore transfer texts into electronic form or generate tactile graphics.

The student assistant is assigned to a lecture - not to a visually impaired student - and is responsible for the correct and timely transfer of the relevant literature into electronic form. In general every third or fourth week during term the so-called student-assistant meeting is held which is attended by the student assistants as well as by visually impaired students and employees of the Study Center. Current questions concerning the transfer of the literature, text lay-out or the organization of the student-assistant programme are discussed at these meetings. 


\section{Counselling and Care}

The close cooperation between the Study Center and the concerned faculties as well as the Center for Information and Guidance (zib) - the Student Counselling Center at the University of Karlsruhe - aims at encouraging the visually impaired prospective students to take their interests and leanings into serious consideration when choosing their courses especially with regard to their future job qualification. Therefore intensive counselling and guidance is offered to visually impaired students of secondary education and those doing the Abitur (school-leaving exam) while they are still at school. Every November an Information Day is held for students of the school years 11 and 12 in connection with a general Open Day organized by the university for school leavers.

Furthermore, an Orientation Unit over several days is scheduled in May for visually impaired students preparing to take their school-leaving exam. During these days information is given on the study courses themselves and on the support provided by the Study Center. At the end of this Orientation Unit, the prospective students should be able to make up their minds about whether they feel up to the study requirements. During terms regular meetings are held in order to give the visually impaired students the possibility to exchange experiences among themselves and with the members of the university (lecturers, fellow students, administration). A network of institutions (Center for Information and Guidance zib, student organization of the individual departments, subject counselling, Psychological Advice Center) offers the corresponding assistance in case of questions and difficulties relating to studying as well a to personal problems.

In cooperation with the university administration, industrial companies, Institutions of the Civil Service and the Center for information and Guidance special possibilities are offered by the Study Center to visually impaired students of qualifying in an effective way for the labour market (e.g. by arranging periods of practical training in industry at home and abroad, application and interview trainings and a special Open Day for industrial companies.

\section{Library}

The Study Center has its own library which is incorporated into the network of scientific libraries. Due to its being a reference library the holdings can't be borrowed as a rule. They comprise the study literature transferred into electronic form for the visually impaired students (i.e. 
diskettes, tactile graphics), its black-print editions, manuals of hardand software as well as literature on subjects relating to handicapped in general and to visually impaired persons in particular.

The study literature transferred on diskette does not fall under the regulation of the reference library; these media can be borrowed by visually impaired students of the University and the Fachhochschule of Karlsruhe.

In addition visually impaired students of other universities may borrow study literature available in electronic form at the Study Center via interlibrary loan. A current catalog of the holdings may be ordered.

\section{University and City of Karlsruhe}

The campus of the university directly borders on the Center of Karlsruhe. The local condition facilitates the visually impaired students' orientation on the campus and in the city. A tactile street map for visually impaired persons and a mobility training plan of the university campus are available. The students have access to nformation on the scientific and cultural activities at the university campus and in town via the local network. Local newspapers, the Student's Offical University Journals, are available on diskette. Thus, an intensive network of institutions and cooperation are set up to provide equal chances to the visually impaired students.

\section{International Cooperation}

During the pilot project phase an international exchange and communication system was established. From 1990 - 1993 a COMETT IIProject was dedicated to the objective of "Integration of Visually Impaired Students into Work by their Completing Practical Training in Europe". A Europe wide network between universities and national and international companies was established. The VIPPRA "Visually Impaired Persons Practical Training", an electronic data base provides information about

- Companies which offer practical trainings for visually impaired students

- students' reports about their personal experience with their practical training

- general and specific news in this field. 
A TEMPUS-Joint European Project (1991-1994) aims at opening university education for visually handicapped students and the improvement of their leaming, living and vocational integration in the Czech and Slovak Republic. In the meantime Study Centers - comparable to the one in Karlsruhe - have been established at the Technical University of Prague and at the Comenius University of Bratislava. We are waiting for the approval of two follow-up applications within the TEMPUS II programme

- "Software Engineering in Market Economy" with a possibility of the integrated study for visually handicapped students at the Technical University of Prague

- "The Improvement and Development of Conditions for Integration of Visually Disabled Persons in Education - Creation of a System for the Preparation of Teachers, Counselors, and Itinerant Teachers acting in/for Integrated Settings" at the Comenius University of Bratislava.

After giving support to build up comparable Centers at the Technical University of Dresden/ Germany and the University of Linz/Austria the Study Center at Karlsruhe now works on a student exchange programme with the University of New Orleans, the Oregon State University and the Queen's University of Kingston (Canada). The first blind student is about to begin his studies abroad.

The pilot project and the activities of the Study Center demonstrate the highly positive way in which modern computer technology and electronic communications can offer new chances in life and at work for handicapped persons and open ways of integration and human normality.

\section{References:}

Joachim Klaus, Ute Lehnerer

Integration von Sehgeschädigten Studierenden und

Hochschulabsolventen in die Arbeitswelt

(COMETT II-Project)

Karlsruhe, 1991 
University Studies of Visually Handicapped Students

Seminar - TEMPUS II - Project

Prague, 1992

New Study and Vocational Possibilities for

Visually Handicapped Students

Seminar -

TEMPUS II - Project, Bratislava, 1993

Joachim Klaus, et al.

Abschlußbericht des Modellversuchs

"Informatik für Blinde - Studium für Sehgeschädigte

in Informatik und Wirtschaftsingenieurwesen"

-Final report-

Bonn, 1994

(being published in "Bildung und Wissenschaft" des Bundesministeriums $f$. Bildung und Wissenschaft) 